\title{
Current Issues Concerning Croatian Coast Guard Role in Marine Casualty Investigation
}

\section{Aktualna problematika uloge obalne straže Republike Hrvatske u istraživanju pomorskih nesreća}

\author{
Željka Primorac \\ University of Split \\ Faculty of Law \\ Split \\ email: zeljka.primorac@pravst.h
}

Summary

In the Republic of Croatia significant amendments of the Maritime Code are being prepared. Among the provisions outlined in the Draft proposal for amending the Maritime Code of August 2018 there are the provisions on marine casualty investigation (defining the concept of marine casualty, dividing marine casualties on very serious marine casualties and serious marine casualties, regulating the procedure of conducting marine casualty investigations and jurisdiction for their enforcement) adopted to improve maritime safety. In view of a continuing trend towards increasing numbers of marine casualties in EU, in this paper the author points out the importance of the topic and critically analyses certain provisions of the national legal system on marine casualties safety investigation activities (Draft proposal for amending the Maritime Code of 2018, Regulation on the manner and conditions for conducting safety investigations of marine casualties and incidents of 2015 and Coast Guard Law of the Republic of Croatia of 2007). The aim of this scientific research is to detect the deficiencies in the national normative framework of Coast Guard support in marine casualty investigations (jurisdiction of the Coast Guard overlapping with jurisdictions of other authorities - nondefinition of competent authorities' joint affairs - nondefinition of the power, methods and procedures of Coast Guard assistance in the investigation of marine casualties) whose removal would contribute to the improvement of the system of safety investigations into marine casualties, identification of the causes of marine casualties and quality performance of the Coast Guard which is at the forefront of ensuring maritime safety.

\section{Sažetak}

U Republici Hrvatskoj pripremaju se značajne izmjene i dopune Pomorskog zakonika. Među rješenjima koje ističe Nacrt prijedloga Zakona o izmjenama i dopunama Pomorskog zakonika iz kolovoza 2018. god. nalaze se i rješenja o istraživanju pomorskih nesreća (o definiranju pojma pomorske nesreće, podjeli pomorskih nesreća na vrlo ozbiljne i ozbiljne, uređenju postupka provođenja istraga pomorskih nesreća te nadležnosti za njihovo provođenje) donesena s ciljem unaprjeđenja sigurnosti plovidbe. S obzirom na stalan trend povećanja broja pomorskih nesreća u EU, autorica u radu upozorava na relevantnost teme i kritički analizira pojedine odredbe nacionalnih pravnih ishodišta glede provođenja sigurnosnih istraga pomorskih nesreća (Nacrt prijedloga Zakona o izmjenama i dopunama Pomorskog zakonika iz 2018.god., Uredba onačinu iuvjetimaza obavljanjesigurnosnih istraga pomorskih nesreća i nezgoda iz 2015. god. i Zakon o Obalnoj straži Republike Hrvatske iz 2007. god.). Cilj je ovog znanstvenog istraživanja otkriti manjkavosti nacionalnog normativnog okvira pružanja potpore Obalne straže u postupcima istraživanja pomorskih nesreća (preklapanje nadležnosti Obalne straže s nadležnostima drugih tijela - nedefiniranje zajedničkih poslova nadležnih tijela - nedefiniranje ovlasti, načina i postupaka pružanja pomoći Obalne straže $u$ istraživanju pomorskih nesreća) čije bi otklanjanje doprinijelo unaprjeđenju sustava provođenja sigurnosnih istraga pomorskih nesreća, utvrđivanju uzroka nastanka pomorskih nesreća te kvalitetnom izvršavanju zadaća Obalne straže, kao nositelju pomorske sigurnosti.
DOI 10.17818/NM/2019/1.5

UDK 347.79(457.5)

Review / Pregledni rad

Paper accepted / Rukopis primljen: 5. 11. 2018.

\section{KEY WORDS}

Croatian Coast Guard

marine casualty investigation

\section{KLJUČNE RIJEČI \\ Obalna straža Republike Hrvatske istraživanje pomorskih nesreća}

\section{INTRODUCTION / Uvod}

The smooth operation of today's maritime transport and safe maritime navigation is threatened by numerous marine casualties. The data from the European Maritime Safety Agency (EMSA) published in the Annual Overview of Marine Casualties and Incidents 2016 (Annual Overview, 2016) has shown that in the period 2011-2015 there were a total of 12,591 marine casualties and incidents involving 14,245 ships, while in the period 2011-2016 there were 16,539 marine casualties and incidents involving 18,665 ships (Annual Overview, 2017). Based on statistical data, we can see that the number of marine 
casualties has been rising steadily (Bužančić Primorac and Parunov, 2016, Eliopoulou et al., 2016) and hence, expeditious safety investigations into marine casualties as part of maritime safety culture (Vatankhan, 2008) are an important element in improving the safety of maritime navigation (Baxter, 1995; Luttenberger, 2012). "Estonia" disaster in 1994 disclosed the weaknesses in the accident investigation system at EU level in identifying and reporting the causes of marine accidents and the lack of close cooperation between EU Member States and their maritime administrations (Vatankhan, 2008). The Third EU Maritime Safety Package of 2009 ("Third Maritime Safety Package" - Erika III package), which contains measures for the improvement of maritime safety standards, has shown the need to improve the safety of maritime navigation, inter alia, requiring from EU Member States to implement provisions on marine casualty investigations in national legal systems by 2010 (Keser, 2011). On 23 April 2009, the European Parliament and the Council adopted Directive 2009/18/EC on ishing the fundamental principles governing the investigation of accidents in the maritime transport sector (Directive 2009/18/ EC) ${ }^{1}$ aimed at reducing the risk of marine casualties by facilitating the expeditious holding of safety investigations and proper analysis of marine casualties. In this way, the harmonisation of investigative methods and procedures in EU Member States and the establishment of cooperation in the investigation of maritime accidents between EU Member States (Bulum, 2011) was to be achieved. Uniform solutions at European level aim to create a uniform system of legal norms valid in all EU countries, so it is necessary to point out the most recent provisions in the Draft proposal for amending the Maritime Code of August 2018 (Draft) ${ }^{2}$ - the basic law of the Republic of Croatia in the area of national maritime (private) law (Barić Punda and Rudolf, 2010), which is in line with the numerous European maritime regulations and the provisions of Directive 2009/18 /EC.

\section{REPORTING AND INVESTIGATING MARINE CASUALTIES ACCORDING TO THE PROVISIONS OF THE DRAFT PROPOSAL FOR AMENDING THE MARITIME CODE OF AUGUST 2018 / Prijava $i$ istraživanje pomorskih nesreća prema rješenjima Nacrta prijedloga Zakona o izmjenama $i$ dopunama Pomorskog zakonika iz 2018. god.}

Across the period 2011-2016, EU States' investigative bodies have launched 869 investigations and 695 reports have been published (Annual Overview, 2017.). Accident investigation methods should be comprehensive in order to ensure that their underlying causes are well-defined and that the activities necessary to modify the problems are affectively implemented (Mousavi and Jafari, 2017). The establishment of a common EU framework within which inquiries following maritime accidents in EU waters are effective, objective

${ }^{1}$ Directive 2009/18/EC is also referred to as the Accident Investigation Directive. Directive 2009/18/EC has a binding character and produces legal effects on the date of its entry into force - 17 June 2009. The scope of application of the provsions of Directive 2009/18/EC are marine casualties and incidents that: a)involve ships flying the flag of one of the Member State; b) occur with in Member States' territorial sea and internal waters or $\mathrm{c}$ ) involve other substantial interests of the Member States(Article 2(2) of Directive 2009/18/EC).

${ }^{2}$ The Draft proposal for amending the Maritime Code of August 2018 was adopted at the 112th session of the Government of the Republic of Croatia (on 30 August 2018) and the Croatian Parliament, on the 9th session held on 12 October 2018 accepted the Draft at the first reading. and transparent (Mandaraka-Sheppard, 2013) has brought about changes concerning the investigation of marine casualties to the Croatian maritime system as well. To be more precise, the Draft completely deletes the provisions of Art. 49 which until then regulated inter alia, also the conduct of a safety investigation (Art. 49(4) of Maritime Code of 2011). ${ }^{3}$ The manner and conditions of conducting safety investigations of marine casualties was prescribed by the Government of the Republic of Croatia through the adoption of a Regulation on the manner and conditions of conducting safety investigations of marine casualties and incidents ${ }^{4}$ (Regulation). According to the provisions of Article 4(1), point (12) of the Regulation, safety investigation is an investigative procedure conducted by the Aircraft, Maritime and Railway Accident Investigation Agency (Agency) ${ }^{5}$ or the investigating authority of another state, during which data is gathered and analysed, determining the causes and causal factors of marine casualties and incidents and, when appropriate, safety recommendations are made to prevent marine casualties and incidents in the future and in that regard to improve maritime safety and reduce the risk of pollution from ships. The Draft provides for the new Chapter I (b) ("Marine Casualty Investigations") which, within the scope of Articles 49 (i) - 49 (n), elaborates in more detail the procedure for conducting marine casualty investigations, defining the concept of marine casualties, ${ }^{6}$ the types of marine casualties, ${ }^{7}$ the powers to carry out investigations and the powers of the Agency. The provision of Article $49(\mathrm{lj})$ of the Draft prescribes the obligation of all public authorities responsible for maritime transport and safety and other public authorities, as well as all natural and legal persons who become aware of the occurrence of a marine casualty or are involved in a marine casualty - to inform the Agency without delay. A detailed legislative provision is contained in Article 9(1) of the Regulation according to which the police, 112 emergency centre, port authorities, port administration offices, maritime carriers and other maritime transport operators (and in particular parties involved in marine casualties and other bodies or persons who are aware that a marine casualty

\footnotetext{
${ }^{3}$ Narodne novine, No. 61/2011 (Official Gazette).

${ }^{4}$ Narodne novine, No. 122/2015 (Official Gazette).

${ }^{5}$ For more details on the activities of the Agency see the Law on Founding the Aircraft, Maritime and Railway Accident Investigation Agency, Narodne Novine, No. 54/2013, 96/2018 (Official Gazette) - Agency's Founding Law.

${ }^{6}$ According to the provision of Art. 49(1) of the Draft, a maritime accident shall be deemed to be an occurrence or a sequence of events which results in: a) death or serious injury to a person caused by, or related to, the performance or operation of a vessel, or b)loss of a person on a vessel that is caused or related to their exploitation or work, or c) loss, presumed loss of a vessel or its abandonment, or d) substantial damage to the vessel, or e) stranding or disablement of the vessel, or its involvement in a collision, or $\mathrm{f}$ ) damage to maritime infrastructure facilities that is caused or related to the operation of the vessel, or g) pollution of the marine environment caused by the damage to the vessel, which is caused or related to its operation.

${ }^{7}$ The Draft introduces a division of marine casualties to serious and very serious marine casualties. A very serious marine casualty means a marine casualty involving complete loss of a vessel, death or serious pollution caused or related to its operation (Article $49 \mathrm{i}(3)$ of the Draft). A serious marine casualty means a marine casualty that is not classified as a very serious accident, and which includes fire, explosion, collision, stranding, impact, weather damage, ice damage, hull fracture or suspected hull defect or other similar damages or defects that result in: a) inability to operate main engines, greater damage to the superstructure, serious damage to the structure (such as leaking of the underwater hull) which prevents the vessel from proceeding; b) pollution of the marine environment, and/or c) malfunction/damage that requirestowing or shore assistence (Art. 49i(4) of the Draft). The a for ementioned legal concept is in full compliance with the provisions of the Regulation.
} 
had occurred within the scope of the Regulation ${ }^{8}$ or it can be concluded from the circumstances of a particular case that it had occurred) - shall forth with, without delay, inform the National Maritime Rescue Coordination Centre (MRCC), which shall without delay transmit the information in the form of a notification to the Agency and the Ministry for Maritime Affairs. The application of the above-mentioned norms regarding the duty of reporting the occurrence of a maritime accident also applies to the Coast Guard.

\section{COAST GUARD SUPPORT IN MARINE CASUALTY INVESTIGATIONS PURSUANT TO THE PROVISIONS OF THE LAW ON COAST GUARD OF THE REPUBLIC OF CROATIA / Pružanje potpore Obalne straže u istraživanju pomorskih nesreća prema rješenjima Zakona o Obalnoj straži Republike Hrvatske}

The duties and tasks that the Coast Guard is authorised to perform have been regulated with the adoption of the Law on Coast Guard of the Republic of Croatia (Law). ${ }^{9}$ The fundamental tasks of the Coast Guard are the protection of sovereignty, sovereign rights and jurisdictions of the Republic of Croatia; the suppression and prevention of terrorism, organized international crime and dissemination of weapons of mass destruction as priorities in the protection of international security; the suppression of piracy and other forms of use of open seas for non-peaceful purposes; search and rescue; protection of the marine environment, nature and cultural heritage; monitoring of marine fisheries and improvement of maritime safety (Articles 14 to 39 of the Law). According to the provision of Article 30(1) of the Law, the Coast Guard provides support at sea to the authorities responsible for monitoring the enforcement of maritime safety regulations (e.g. port authorities, MRCC, police and other state bodies). The Croatian legislature has clearly indicated the scope of cooperation between the Coast Guard and the authorities responsible for monitoring the enforcement of maritime safety regulations, prescribing that the said co-operation relates to the Coast Guard's involvement in carrying out the following activities: monitoring of ships on the Adriatic Sea (Article 30(2) of the Law) as well as reporting and supporting the investigation of marine casualties in the open seas (Article 30(3) of the Law). It is important to note that the legislative provision does not specify to what type of investigation of marine casualties,

\footnotetext{
${ }^{8}$ The Regulation applies to marine casualties and incidents that: 1) involve vessels flying the flag of the Republic of Croatia (RH),irrespective of the location of the casualty or incident; 2) occur within territorial sea and internal waters of the Republic of Croatia,as defined in the United Nations Convention on the Law of the Sea of 10 December 1982, irrespective of the flag of the ship or the ships involved in the casualty; 3 ) occur in other waters if aro-ro passenger ship or a high-speed passenger craft on a regular service of the nationality of a Member State was involved in the casualty or incident, to which the Republic of Croatia was the Member State of last port call, until the agreement is achieved between the Aircraft, Maritime and Railway Accident Investigation Agency and the investigating authority of the substantially interested Member Stateon taking over a safety investigation by that Member State and 4) include other essential interests of the Republic of Croatia, irrespective of the location of the casualty and the flag of the ship or ships involved in the casualty (Article 3(1) of the Regulation). It can be concluded that the Regulation provides a more detailed and standardised scope of applicationin relation to Directive 2009/18/EC (see note 1).

${ }^{9}$ Narodne novine, No. 109/2007 (Official Gazette). The Law came into force on 1 November 2007.
}

safety investigation or administrative investigation ${ }^{10}$ the Coast Guard can provide support. ${ }^{11}$

We can note that the Coast Guard is not obligated to report and support the investigation of a marine casualty, but has the authority to provide support in the investigation of a marine casualty ("the Coast Guard can..."). Furthermore, the law explicitly provides for a territorial restriction with respect to reporting and supporting the investigation of marine casualties by the Coast Guard - in open seas. It is important to note that the highest traffic density is on the main longitudinal route in the central part of the Adriatic open sea which should not be neglected if we take into account the increasing trend of marine casualties (Lušić et al., 2011). The meaning of the provision of Article 30(3) of the Law corresponds to the purpose for which the Coast Guard was established.More specifically, according to the provisions of Article 1(2) of the Law, the fundamental duties and tasks of the Coast Guard are the protection of sovereign rights and the assertion of the jurisdiction of the Republic of Croatia in the protected ecological fishing zone, on the continental shelf and in the open sea.Although no state has an exclusive power in the open sea nor can it acquire or put any part of that sea under its sovereignty (Rudolf, 2010), the provision of Article 94(7) of the United Nations Convention on the Law of the Sea prescribesthe duty of the flag State to launch an investigation of any marine casualties in the open sea involving a ship sailing under its flag that caused loss of life or serious injury to the citizens of another Stateor considerable damage to ships or equipment of another State or to the marine environment. It is a provision that corresponds to the Croatian provisions. More specifically, the Coast Guard may report and support the investigation of marine casualties in the open sea involving a boat flying the Croatian flag which caused loss of life or serious injury to the citizens of another State or considerable damage to ships or equipment of another State or to the marine environment.

Under the general provision of Article 30(3) of the Law the procedure of reporting and providing support in the investigation of marine casualties by the Coast Guard has been regulated. More detailed rules regarding the authority

\footnotetext{
${ }^{10}$ Marine Casualty Investigation Code of 2007, Narodne Novine, No. 9/2007 (Official Gazette), which is no longer in force, provided that the administrative investigation be carried outwith a view to determining liability for marine casualty. The Code on methods, conditions and powers for carrying out an administrative investigation of marine casualties (Narodne Novine, No. 69/2016 (Official Gazette)) which is now in force, prescribes methods, conditions and powers for carrying out an administrative investigation of marine casualties for the purposes of gathering evidence and data in order to establish liability for criminal and misdemeanour offences related to marine casualties, with the aim of detecting the perpetrator and discovering objects, leads and other evidence that can be used in determining the facts in a criminal or misdemeanour procedure.

${ }^{11}$ Here we can note that the provisions of the Law correspond to the provisions of the United Nations Convention on the Law of the Sea of 1982 (adopted on 10 December 1982, entered into force on 16 November 1994, binding upon the Republic of Croatia from 5 April 1995 - Narodne Novine, International Agreements, No. 9/2000 (Official Gazette) and the Maritime Code of 2004 (Narodne Novine, No. $181 / 2004$ (Official Gazette)), which was then in force and which pursuant to the provision of Article 49 did not make a distinction between a safety investigation and/or an administrative investigation of marine casualties. However, Marine Casualty Investigation Code of 2007 had already laid down the conditions, procedures, methods and powers for carrying out investigations ofmarine casualties (safety investigations and administrative investigations). Thus, under the aforementioned Code the conduct of maritime safety investigation (Articles 8-21) and administrative investigation (Articles 22-33) was regulated. It is only under the Maritime Code of 2011 that a division to a safety and administrative investigation of marine casualties was made, clearly defining the objectives of their implementation and the powers to carry them out within the scope of one regulation.
} 
of the Coast Guard in reporting marine casualties are contained in Article 49lj of the Draft.In relation to the Coast Guard support procedures in carrying out a marine casualty investigation - the aforementioned procedure (defining authority, establishing a modus operandi, etc.) is not included in a special regulation that would more comprehensively regulate this important role of the Coast Guard.

\subsection{The role of the Coast Guard in conducting marine casualty safety investigations pursuant to the provisions of the Regulation / Uloga Obalne straže $u$ provođenju sigurnosnih istraga pomorskih nesreća prema rješenjima Uredbe}

When performing basic coastguard duties, Coast Guard members shall comply with current international, European and national regulations that regulate certain segments of their jurisdiction. Therefore, the provisions of Directive 2009/18/EC, the Maritime Code, the Law and the Regulation apply to their modus operandi. The main task of the Agency is to initiate and conduct a safety investigation in the event of a marine casualty. According to the provisions of Article $49 \mathrm{k}(1)$, (2), (3) of the Draft, a safety investigation shall be carried out independently from any other investigation of marine casualties carried out by other national authorities with the aim of establishing the circumstances and causes that led to the marine casualty and proposing corrective measures for their prevention and repetition, the improvement of maritime safety and the reduction of risks of marine casualties and their consequences on the marine environment and the resulting sea pollution. Safety investigations are not concerned with determining liability or apportioning blame or imposing administrative, civil or criminal liability (Art. 1(1), point (3) of the Regulation) and in theory they are referred to as "no-blame safety investigations" (Vatankhan, 2008; Kavanagh, 2008). It is precisely in conducting maritime safety investigations that the role of the Coast Guard is emphasized by the Regulation. Specifically, the Regulation provides for a particularly standardised work of investigators in the conduct of safety investigations, i.e. the authority of the investigator-in-charge, ${ }^{12}$ the authorised investigator $^{13}$ and other investigators ${ }^{14}$ of the Agency involved in the safety investigation of a marine casualty to request and obtain, among others, from the Coast Guard of the Republic of Croatia:

1) have free and unhampered access to any relevant area and casualty or incident site as well as all the witnesses, ships and structures involved in the casualty or incident, wreckage, debris, cargo, equipment, information from charts and log books, electronic and magnetic recording and video tapes, including information from VDRs and other electronic devices relating to the period preceding, during and after an accident and other equipment and information which might reasonably be considered pertinent to the safety investigation of the accident;

\footnotetext{
${ }^{12}$ Investigator-in-charge is a person appointed as an investigator in charge of marine casualties in accordance with the provisions of the Agency's Founding Law. For more detail on the appointment, dismissal and powers of the investigator-incharge see Art. 10 of the Agency's Founding Law.

${ }^{13}$ Authorised investigator is a person who, under the authority of the investigator in-charge, conducts a specific safety investigation of a marine casualty or incident and actively investigates the causes of a marine casualty or incident (Article 4 (1), point (17) of Regulation).

${ }^{14}$ Investigator is a person who, under the authority of the investigator-in-charge or the authorised investigator, carries out specific investigative actions and participates in a safety investigation of a marine casualty or incident (Article 4 (1) point (18) of Regulation).
}

2) taking actions to preserve material evidence, in particular taking measures to: a) save all information from charts, log books, electronic and magnetic recording and video tapes, including information from VDRs and other electronic devices relating to the period preceding, during and after an accident; b)prevent the overwriting or other alteration of such information; c) preserve any other equipment which might reasonably be considered pertinent to the safety investigation of the accident; and

3) assistence from members of the Coast Guard ${ }^{15}$ of the Republic of Croatia in the accident that is being investigated.

Ad 1) To exercise these powers, the Agency's investigators can, in addition to the Coast Guard of the Republic of Croatia, also contact the following: public prosecutor, police, port authorities, port administration offices, maritime carriers and other maritime transport operators(Article 16(1), point (1) of the Regulation).

Ad 2) To exercise these powers, the Agency's investigators can, in addition to the Coast Guard of the Republic of Croatia, also contact the following: public prosecutor, police, port authorities, port administration offices, maritime carriers and other maritime transport operators as well as persons involved in an accident or incident (Article 16(1), point (2) of the Regulation).

Ad 3) Apart for the Coast Guard members, Agency's investigators may request and obtain assistance from all public authorities, harbour masters and port authorities' employees, operators of vessel traffic control and monitoring systems, MRCC operators, pilots and other port or maritime personnel regarding the accident they are investigating (Art. 16(1), point (11) of the Regulation). Although Coast Guard procedures might be quite extensive and complex, the Regulation does not fully regulate the way in which the Coast Guard should operate in such cases as, for example, how to preserve material evidence, what can be considered as material evidence, etc.

In cases 1), 2) and 3), the wording "request and obtain" is used, which clearly points to the fact that the Coast Guard must comply with the request of the competent persons of the Agency.

The Regulation stipulates that the investigator-in-charge, the authorised investigator and other investigators of the Agency involved in the safety investigation of a marine casualty have the authority to request from the Coast Guard of the Republic of Croatia:

4) gathering and/or preserving as well as using and copying evidence for the purposes of a safety investigation; and

5) requiring assistence from the officers of the Coast Guard of the Republic of Croatia regarding the accident they are investigating.

Ad. 4) The Agency's investigators may also require these measures to be taken by: public prosecutor, police, port authorities, maritime carriers and other maritime transport operators as well as persons involved in an accident or incident (Article 16(1), point (3) of the Regulation).

Ad. 5) The Agency's investigators may also require assistence from: competent authorities of other States, in particular the inspectors of the flag State and the port State, vessel traffic monitoring operators, search and rescue authorities, pilots and other port or maritime personnel regarding the accident they are

${ }^{15}$ Coast Guard members are officers, petty officers and sailors/soldiers as well as civil servants and employees of the Armed Forces of the Republic of Croatia posted in the Coast Guard as authorized or unauthorized persons of the Coast Guard (Article 5 (2) of the Law). Acquiring the status of an authorized person of the Coast Guard is prescribed by the Code on acquiring the status of anauthorized person of the Coast Guard, Narodne Novine, No. 98/2015 (Official Gazette). 
investigating (Article 16(1), point (12) of the Regulation).

In cases 4) and 5), the wording "request" is used, but not "obtain" as in cases 1), 2) and 3). Given the existence of loopholes, a legal void has been created that allows the investigator-incharge, the authorised investigator and other investigators of the Agency to participate in the conduct of a marine casualty investigation to "request and obtain" assistance from members of the Coast Guard of the Republic of Croatia regarding the accident they are investigating, but also to "request" (not "obtain") the assistance from members of the Croatian Coast Guard regarding the accident they are investigating. Since the provisions in question do not provide for a clear demarcation, and the issues on how to provide Coast Guard support have not been regulated (scope of action, etc.) - it is clear that the aforementioned legal provision will not contribute to the high-quality performance of these activities.

It is extremely important to point out that the Croatian legal provisions on providing assistance to the Agency's competent officers arose out of the general provision contained in Article 8(4) of Directive 2009/18/EC, which stipulates the investigative bodies' powers for conducting safety investigations, and among other things, the power to require assistance from competent authorities in the countries concerned (including the assistance of the Coast Guard). The European legislature did not provide details on the scope of the Coast Guard assistance in conducting marine casualty safety investigations, leaving to the EU Member States to establish a suitable form of cooperation within their legal systems. The Republic of Croatia has in part done this by adopting the Regulation, but there are no adequate legal norms that would better regulate the manner, conditions and powers of the Coast Guard members in carrying out the important task of providing support in a marine casualty investigation.

\section{PROTOCOL ON THE PRACTICE OF CONDUCTING INQUIRIES AND GATHERING EVIDENCE FOR CRIMINAL OFFENCES RELATED TO AIR, MARITIME AND RAILWAY TRAFFIC BY THE PUBLIC PROSECUTORS, POLICE AND INVESTIGATORS OF THE AIRCRAFT, MARITIME AND RAILWAY ACCIDENT INVESTIGATION AGENCY / Protokol o postupanju državnih odvjetnika, policije i istražitelja Agencije za istraživanje nesreća u zračnom, pomorskom i željezničkom prometu u provođenju izvida i prikupljanju dokaza kod kaznenih djela vezanih uz nesreću u zračnom, pomorskom $i$ željezničkom prometu}

The legal arguments presented in the previous chapter are further emphasized by the analysis of the provisions of Article $16(3)$, (4) of the Regulation stipulating that in carrying out a safety investigation the police shall cooperate with the investigator-incharge, authorised investigator and other Agency's investigators (in accordance with the special regulation on police affairs and authorities - Law on Police Affairs and Authorities ${ }^{16}$ ) and public prosecutor (in accordance with special regulations on criminal procedure - Criminal Procedure Act ${ }^{17}$ and in accordance with special regulations on the State Attorney's Office - Law on the State Attorney's Office $\left.{ }^{18}\right)$. The aforementioned bodies will jointly

\footnotetext{
${ }^{16}$ Narodne novine, No. 76/2009, 92/2014 (Official Gazette).

${ }^{17}$ Narodne novine, No. 152/2008, 76/2009, 80/2011, 91/2012, 143/2012, 56/2013, 145/2013, 152/2014, 70/2017 (OfficialGazette).

${ }^{18}$ Narodne novine, No. 67/2018 (OfficialGazette).
}

cooperate with the Agency with regard to carrying out an inspection and an inquiry into marine casualties and accessing evidence for purposes of conducting a safety investigation of a marine casualty. Under the provision of Article 15(5) of the Regulation it is stipulated that the implementation of the joint cooperation between the Agency, the police and the State Attorney's Office will be more closely regulated by a special protocol. In order to improve the joint cooperation between public prosecutors, police and the Agency, and to address and regulate certain issues of importance for the investigation of accidents, on 22 July 2015, a Protocol on the practice of conducting inquiries and gathering evidence for criminal offences related to air, maritime and railway traffic by the public prosecutors, police and investigators of the Aircraft, Maritime and Railway Accident Investigation Agency was adopted (Protocol). ${ }^{19}$ Clearly pointing out that the important issues for the investigation of marine casualties are also considered to be issues regulated by Directive 2009/18/EC, the Protocol provides for a well-defined jurisdiction of the police, the State Attorney's Office and the Agency in the marine casualty investigations. Pursuant to the provisions of Art.1(1) of the Protocol, in the case of a marine casualty, the police or the State Attorney's Office carry out the necessary measures of inquiry and inspection, and the Agency's investigators conduct a safety investigation. In order to meet the conditions for conducting a safety investigation, the public prosecutor when carrying out an inspection or the police if the inspection is not carried out by the public prosecutor shall ensure that the Agency's investigators have access to the location of the marine casualty and to evidence gathered during the inquiry and investigation (Art. 2(1), Art. 9(1) of the Protocol). Here we can see that the provision of Article 16(3) and (4) of the Regulation does not prescribe the cooperation of the Coast Guard and the Agency, following the example of the cooperation with the police and the State Attorney's Office, and the Protocol does not apply to members of the Coast Guard. In accordance with the provisions of the said Protocol, it is suggested that with regard to the Coast Guard's role in the investigation of marine casualties its duties and powers be regulated by a special Protocol on cooperation between the Coast Guard and the Agency in the investigation of marine casualties. In this way, the signatories of the Protocol would agree to regulate the issue of jurisdiction over certain procedures undertaken both by the Agency and by the Coast Guard, taking into account the importance of their fundamental roles, the wide range of jurisdiction of the Coast Guard prescribed by laws and bylaws, the overlapping of Coast Guard jurisdiction with those of other bodies responsible for monitoring the enforcement of maritime safety regulations by establishing an indispensable level of knowledge of procedural methods for the investigation of maritime accidents and the competence of professional personnel.

\section{CONCLUSION / Zaključak}

Marine casualties threaten the safety of maritime navigation and the objective of the EU Member States is to reduce the risk of their occurrence.One of the measures that should contribute to reducing the risk of marine casualties in the future is the conduct of investigative procedures that are not intended to attribute guilt or liability for the occurred marine casualty (safety investigations of marine casualties). Based on the new provisions of the Draft on

${ }^{19}$ The Protocol is applicable as from 15 August 2015 
conduct of marine casualty investigations, the role of the Coast Guard in their implementation cannot be discerned.Likewise, the Law also contains a scant legal norm stating that the Coast Guard shall be involved in reporting and providing support for a marine casualty investigation in the open seas (Article 30(2) of the Law), without reference to what type of maritime casualty investigation is the Coast Guard allowed to participate in, without defining what measures and procedures the Coast Guard is authorized to undertake when providing support in the investigation of marine casualties. The provisions of the Regulation further regulate the manner and conditions for carrying out safety investigations of marine casualties, also highlighting the role of the Coast Guard in their implementation. In pointing out open issues that are not legally regulated, the author discusses the real need to clearly define the powers and scope of the Coast Guard and the Agency's coordination in the investigation of marine casualties (modelled on the provisions of the Protocol on joint cooperation between the Agency, police and public prosecutor in conducting a safety investigation of a marine casualty) by prescribing the concrete procedures the Coast Guard is authorized to undertake in the investigation of marine casualties and the manner in which they are to be carried out. There is no doubt that the Coast Guard can play an important role in gathering and analysing data on marine casualties and the causal factors of their occurrence and thus help the Agency in conducting a safety investigation of a marine casualty. However, the author points out that it is necessary to delimit the jurisdiction of the Coast Guard in taking said measures from the jurisdiction of, e.g. port authorities, port administration offices, MRCC and others, from which the Agency is also authorized to request assistance in conducting safety investigations of marine casualties. A clear delimiting of the powers and competencies to conduct safety investigations of marine casualties by having Coast Guard take independent measures, that is, measures of joint, coordinated, clear and effective cooperation of the Coast Guard and e.g. the Agency or port authority (establishing conditions that must be met in order to have a clear view of the joint procedures, the way in which the said procedures are carried out, the powers and responsibility of each of the competent authorities participating in the joint procedures, etc.) will contribute to the improvement of the system of conducting safety investigations of marine casualties. High-quality, systematic and comprehensive regulation of Coast Guard powers in conducting the procedures of a marine casualty safety investigation, will not have a positive impact unless the construction and/or acquisition of at least one Coast Guard offshore patrol ship for carrying out tasks in the open sea is provided, as well as professional training and upskilling of the Coast Guard members for conducting safety investigations of marine casualties. The realization of a logistical and infrastructural support in carrying out basic Coast Guard tasks and the provision of financial means for their performance are necessary prerequisites for the Coast Guard to function as an important factor in the improvement of the safety of maritime navigation and for the establishment of an organised system of monitoring and protection of Croatian rights and interests at sea.

\section{REFERENCES / Literatura}

[1] Annual Overview of Marine Casualties and Incidents 2016, EMSA, pp. 8,15-16. http://www.emsa.europa.eu/news-a-press-centre/external-news/item/2903 annual-overview-of-marine-casualties-and-incidents-2016.html
[2] Annual Overview of Marine Casualties and Incidents 2017, EMSA, pp.9,17. http:// www.emsa.europa.eu/news-a-press-centre/external-news/item/3156-annualoverview-of-marine-casualties-and-incidents-2017.html

[3] Barić Punda, V.; Rudolf, D.: Komentar javnopravnih odredbi Pomorskog zakonika, Pravni fakultet u Splitu, Split, 2010., pp. 12.

[4] Baxter, T.: Independent investigation of transportation accidents, Safety Science, vol. 19, no. 2-3, 1995, pp. 271-278. https://doi.org/10.1016/0925-7535(94)00029-3

[5] Bulum, B.: Pomorski promet, in: Europsko prometno pravo, Pravni fakultet u Zagrebu, Zagreb, 2011, pp. 328

[6] Bužančić Primorac, B.; Parunov, J.: Review of statistical data on ship accidents, Maritime Technology and Engineering 3, Taylor \&Francis Group, 2016, pp. 814. https://www.fsb.unizg.hr/usb_frontend/files/1468312217-0-ch094.pdf

[7] Coast Guard Law of the Republic of Croatia of 2007, Narodne novine, No. 109/2007 (Official Gazette)

[8] Criminal Procedure Act, Narodne novine, No. 152/2008, 76/2009, 80/2011, 91/2012, 143/2012, 56/2013, 145/2013, 152/2014, 70/2017 (Official Gazette)

[9] Directive 2009/18/EC of the European Parliament and of the Council of 23 April 2009 establishing the fundamental principles governing the investigation of accidents in the maritime transport sector, OJ, L 131 28/05/2009, pp. $114-131$. https://eur-lex.europa.eu/legal-content/EN/TXT/HTML/?uri=CELEX:32009L0018 \&from $=\mathrm{HR}$

[10] Draft proposal for amending the Maritime Code of August $2018 \mathrm{https} / / / \mathrm{vlada} . g o v$. $\mathrm{hr} /$ UserDocsImages/Sjednice/2018/08\%20kolovoz/112\%20sjednica/112\%20 -\%201.pdf

[11] Eliopoulou, E.; Papanikolau, A.; Voulgarellis, M.: Statistical analysis of ship accidents and review of safety level, Safety Science, vol.85, 2016, pp. 282-292. https://doi. org/10.1016/j.ssci.2016.02.001

[12] Kavanagh, J.: Marine inquiries: Balancingthe "no-blame“ investigation with the regulatory investigation to achieve marine safety outcomes, Australian\& New Zealand Maritime Law Journal, vol. 22, no. 2, 2008, pp. 177-219. http://www. austlii.edu.au/au/journals/ANZMarLawJ/2008/16.pdf

[13] Keser, I.: The Common Maritime Transport Policy of the European Union - the Protection and Preservation of the Marine Environment, Poredbeno pomorsko pravo, vol. 50, no. 165, 2011, pp. 291.

[14] Law on Founding the Aircraft, Maritime and Railway Accident Investigation Agency, Narodne Novine, No. 54/2013, 96/2018 (Official Gazette)

[15] Law on Police Affairs and Authorities, Narodne novine, No. 76/2009 (Official Gazette)

[16] Law on the State Attorney's Office, Narodne novine, No. 67/2018 (Official Gazette)

[17] Lušić, Z:; Pušić, D.; Galić, S.: Pomorski promet i nezgode na hrvatskom dijelu Jadrana, International Conference on MaritimeScience, Solin, 2011, Book of Proceedings, pp. 157, 159.

[18] Luttenberger, A.: Improving legal standards in marine accident investigation activities, Proceedings IMLA 20. West Terschelling, Maritime Institute Willem Barentsz, The Netherlands, 2012, pp. 1.-3.

[19] Mandaraka-Sheppard, A.: Modern Maritime Law, vol. 2.: Managing risks and liabilities, CRC Press, 2013, pp. 43.

[20] Marine Casualty Investigation Code of 2007, Narodne Novine, No. 9/2007 (Official Gazette)

[21] Maritime Code of 2004, Narodne Novine, No. 181/2004 (Official Gazette)

[22] Maritime Code of 2011, Narodne novine, No. 61/2011 (Official Gazette)

[23] Mousavi, M.; Jafari, M.: Marine accidents investigation methods based on the role of human factors in accidents, International Journal of Scientific Study, vol. 5 , issue 6, 2017, pp. 264. DOI:10.17354/ijssSept/2017/48

[24] Protocol onthe practice of conducting inquiries and gathering evidence for criminal offences related to air, maritime and railway traffic by the public prosecutors, police and investigators of the Aircraft, Maritime and Railway Accident Investigation Agency, https://www.mup.hr/UserDocslmages/PDF/ Protokol\%20o\%20suradnji\%20MUP,\%20DORH\%20i\%20AIN/Protokol\%20o\%20 postupanju\%20Dr\%C5\%BEavnog\%20odvjetni\%C5\%A1tva,\%20MUP-a\%20-\%20 Ravnateljstva\%20policije\%20i\%20Agencije\%20za\%20istra\%C5\%BEivanje\%20nesre\%C4\%87a\%20u\%20zra\%C4\%8Dnom,.pdf

[25] Regulation on the manner and conditions for conducting safety investigations of marine casualties and incidents of 2015, Narodne novine, No. 122/2015 (Official Gazette)

[26] Rudolf, D.: Enciklopedijski rječnik međunarodnog prava mora, Matica Hrvatska, Zagreb, 2010, pp. 536.

[27] The Code on acquiring the status of an authorized person of the Coast Guard, Narodne Novine, No. 98/2015 (Official Gazette)

[28] The Code on methods, conditions and powers for carrying out an administrative investigation of marine casualties, Narodne Novine, No. 69/2016 (Official Gazette)

[29] United Nations Convention on the Law of the Sea, Narodne novine, International Agreements, No. 9/2000 (Official Gazette)

[30] Vatankhan, S.: EU - Regulations on Inquiries into Maritime Casualties, in: Enforcement of International and European Union Law in Maritime Affairs, LIT Münster, 2008, pp. 117, 129, 132. 